Article

\title{
The Adoption of Environmental Practices in Small Hotels. Voluntary or Mandatory? An Empirical Approach
}

\author{
Llorenç Bagur-Femenias $^{1, *}$, Dolors Celma ${ }^{2}$ and Josep Patau ${ }^{2}$ \\ 1 Accounting and Finance Department, UPF Barcelona School of Management, Barcelona 08008, Spain \\ 2 Escola Superior de Ciències Socials i de l'Empresa de Tecnocampus, Universitat Pompeu Fabra, \\ Mataró 08302, Spain; mdcelma@tecnocampus.cat (D.C.); jpatau@tecnocampus.cat (J.P.) \\ * Correspondence: llorenc.bagur@upf.edu; Tel.: +34-93-542-18-00
}

Academic Editor: Ian Patterson

Received: 5 May 2016; Accepted: 18 July 2016; Published: 21 July 2016

\begin{abstract}
This paper examines small hotels that have some type of environmental certification. A survey of 210 small (less than 50 employees) Catalonian hotels was conducted to investigate whether there are significant differences in the results of the implementation practices between hotels that adopt these certifications due to environmental pressure (from the government, customers, suppliers and other stakeholders) and hotels that voluntarily commit to green policies. Significant differences were identified in the results on the hotels when structural equation modelling (SEM) was undertaken. This investigation suggests that hotels that voluntarily commit to green policies obtain better results than other hotels. The conclusion is that governments must not only regulate, but also promote awareness actions in small and medium-sized (SME) tourism companies to improve the environment. SME tourism companies must understand that both the environment and they themselves will benefit.
\end{abstract}

Keywords: sustainability; environmental practices; hotels; environmental certification; SME; tourism

\section{Introduction}

In 2014, Catalonia received 16.8 million international tourists who spent $15,113.7$ million euros, of which 3275.1 million $(21.7 \%$ ) were lodged in some type of establishment $[1,2]$. In view of these data, the importance of tourism and the hotel sector as important driving forces of the Catalan economy is indisputable. To maintain this primacy, the hotel sector requires systems that regenerate its supply and a process of continuous improvement and innovation to meet demand, without affecting the environment and bearing social welfare in mind [3].

The exponential growth of the tourism sector in recent years has revealed the need to be more conscious of the impact of this sector, especially by hotels, on the environment [4]. As a result, environmental management has played an increasingly more important role in the hotel sector [5]. The hotel sector in Spain is increasingly proactive in the voluntary adoption of environmental practices, especially with the implementation of ISO 14001 environmental certification and Eco-Management and Audit Scheme (EMAS) environmental management of the European Union; in 2005, 80\% of hotels with EMAS certificates in Europe were Spanish. This number continues to grow [4], and in the same year, ISO 14001 was the most frequently used environmental management standard, with Spain and Italy being the European countries with the highest number of ISO 14001 certifications in the services sector, an important number of which were in the hotel sector [6].

In general, proper environmental management, while contributing to sustainable development [7], also allows companies to save costs and, thus, optimize their operating results $[8,9]$ and increase the 
demand from environmentally-conscious consumers [10]. In addition, there are studies [11-13] that indicate that the implementation of environmental measures and their subsequent certification can produce better operating results and improvements in the image of the company.

In the specific case of the hotel sector, evidence suggests that when a hotel adopts new management systems that incorporate the certification of environmental measures, its operating performance improves and it is viewed more positively [13,14]; the same opinion has been adopted by [15], who explains that, when some type of environmental certification is established in hotels, such as environmental management systems and eco-labels, the attainment is much greater in terms of improving the environmental and sustainable performance of the company.

In regard to the motivations for the adoption of environmental practices (EPs), previous studies, such as those by $[14,15]$, show that hotels adopt these practices primarily due to legal pressure and demands from stakeholders, such as customers or suppliers; other hotels also do the same, but voluntarily, adopting codes of conduct, eco-labels and environmental management systems.

Based on this philosophy of action, this article focuses attention on a sample of small hotels (less than 50 employees) in Catalonia that already have some type of environmental certification. The objective is to observe whether there are significant differences, both at the operational level and at the level of image and reputation, in the results of the implementation of EPs among hotels that adopt these certifications on a voluntary basis and among those that do so under pressure.

This study illuminates different aspects: first, there are already studies on the adoption of EPs in the hotel sector [16-21], and some of them have already indicated the competitive advantages of implementing proactive initiatives for certain environmental issues: [22] finds that performance levels increase as environmental proactivity grows; [23] finds that the link between environmental management practices and financial performance is stronger for proactive hotels; [24] suggest that a proactive environmental stance is vital to maintain the image of hotels; and [20] claim that hotels proactive on environmental issues have a higher level of economic performance. However, to the best of our knowledge, there are no studies specifically focused on studying the differences in the results obtained depending on whether the EPs are adopted voluntarily or under pressure, and few studies are focused on small hotels. Second, this study provides arguments to small hotels for the voluntary adoption of environmental certifications, given their impact on the results. Finally, this study provides evidence of the positive effects of environmental protection from both social and business perspectives. As [25] stress, managers should consider how their decisions affect society as a whole and contribute to sustainable development.

The remainder of this paper is structured as follows. Section 2 discusses the motivations for the adoption of EPs and certifications in the hotel industry and the relationship between the adoption and its impact. Section 3 describes the empirical design of this study. Section 4 presents a quantitative analysis with the results. Finally, the article concludes: recommendations, limitations and future research for hotel management are presented, and conclusions are discussed.

\section{Review Literature}

\subsection{Adoption of Environmental Practices and Certifications in the Hotel Industry}

The social awareness of environmental issues, together with the regulations that are produced, has led organizations to change their attitudes towards environmental protection. Many organizations have moved from a reactive and short-term position in solving environmental inefficiencies to proactive environmental behaviors that enable competitive advantages [26]. However, environmental management approaches are not homogeneous because they depend on numerous determinants, such as organizational resources, management values or the conditions of the market and industry [27]. This has led to two types of behavior: reactive and proactive. The reactive behaviors are short-sighted and mainly involve adapting the organization to basic environmental regulations. 
By contrast, proactive approaches require that companies voluntarily go beyond the regulations to implement actions to prevent environmental degradation [28].

Thus, on the one hand, the adoption of EPs by companies has been increasing as regulations in this regard have been created. Different mandatory regulations force companies to adopt environmentally-friendly behaviors. In Europe, there are directives designed to assess the effects of certain public and private projects on the environment [29]. The main feature of this policy is to include environmental issues, such as the efficient use of resources and the sustainability thereof, the protection of biodiversity, climate change and risks of accidents and disasters, as important elements in the process of evaluation and decision making. In addition, public and private projects must take into account and limit their impact on the land, especially its status and, particularly organic, matter, erosion, compaction and sealing, among others. Greater emphasis is placed on the obligation of states to ensure that mitigation measures and compensation apply and the establishment of appropriate procedures for monitoring significant adverse effects that may unexpectedly arise so that they can take the appropriate corrective action; however, in merely being a policy, the door is left open for non-application in certain cases: if provided by national law, EU Member States may decide not to apply this Directive to projects or parts of projects whose sole objective is defense or projects whose sole objective is response to a civil emergency if they deem that such an application can have adverse effects on these objectives.

At the state level, countless local regulations establish rules that govern the environmental assessment of plans, programs and projects that may have significant effects on the environment, guaranteeing the entire Spanish territory a high level of environmental protection to promote sustainable development. Particularly in Catalonia, the territorial subject of our study, there is Law 20/2009 on the Prevention and Control of Activities, which entered into force in August 2010 [30] and repealed the previous Law 3/1998 on the Comprehensive Intervention of the Environmental Administration. Law 20/2009 aims to establish a system of administrative intervention into activities with an environmental impact, taking into consideration the effects on people and on the environment. The main objectives of this law are as follows:

(a) to achieve a high level of protection of people and the environment as a whole, to ensure their quality of life through the instruments necessary to prevent, minimize, correct and control pollution and make efficient use of resources and raw materials;

(b) to promote sustainable development through an environmental administrative intervention to harmonize economic and social development with environmental protection;

(c) to contribute to enforcing the criteria of efficiency and service to the public in the instruction of administrative procedures and to ensure the collaboration and coordination of the public administrations that must intervene;

(d) to facilitate the action of productive activity with environmental protection in a respectful manner.

On the other hand, with regard to the mandatory regulations noted above, there are also different voluntary environmental management tools that companies can adopt, such as codes of conduct, indicators of environmental performance, and, even further, environmental certifications, such as eco-labels and environmental management systems [15]. In the tourism sector, an increasing number of companies are becoming environmentally certified through the environmental management systems ISO 14001 and EMAS of the European Union [4,13]. However, other environmental management measures have indirectly been adopted in Spain through the implementation of voluntary systems of quality certification for tourism [31]. More specifically, since 1996, a project known as the Spanish Tourism Quality System has been implemented to create specific quality systems mainly for hotels, travel agencies and restaurants.

The adoption of EPs is especially important in the hotel sector [32]. Although this sector does not entail, a priori, the consumption of large quantities of non-renewable resources, it has a significant effect on global resources [33], especially in Spain, where tourism represents $10.9 \%$ of the gross domestic 
product (GDP) of the country [34]. Thus, the operation of hotels implies activities that require the consumption of substantial volumes of water or the use of environmentally harmful materials, such as disposable plastic containers, non-recyclable packaging and detergents, among others [23], with the consequent progressive degeneration of the environment. This has made the adoption of EPs a topic of growing interest in this business.

Environmental management practices are generally adopted for various reasons. One especially important reason is pressure from stakeholders [35], although the proactive attitude of managers towards environmental protection is also a determinant [7]. For small businesses, the pressure to adopt EPs mainly comes from customers, the government, the local society, employees, suppliers and others, such as competitors, banks and insurance companies [36-38].

More specifically, in the hotel industry, the concern for the implementation of EPs, in addition to deriving from legislative regulations, also derives from the growing environmental awareness among the general population and among consumers, who are increasingly considering these aspects when choosing their tourist destinations $[14,33]$. Similarly, EPs are also being voluntarily adopted as employers consider that their adoption is strategic for the business $[19,22,24,39,40]$.

\subsection{Impact of the Adoption of Environmental Practices on Operational Performance and Competitiveness in the Hotel Industry}

Despite the recent concern for the social, environmental and economic perspectives of sustainability, little is known about the drivers of sustainability in companies [41]. With regard to the environmental perspective, some authors argue that environmental management continues to be of great competitive and strategic importance in most sectors $[19,42,43]$. Through environmental management, companies can become more efficient and meet the needs of ecological consumers who appreciate the environmental concern of companies and the environmental impact of their products $[44,45]$.

Companies adopt EPs with the aim of achieving operational improvements, such as cost savings [46], improvements in employee health and safety standards [47] or the use of government subsidies to achieve more sustainable production methods $[48,49]$. In the hotel sector in particular, the adoption of EPs often also helps improve hotels' efficiency and results [20]. Some authors suggest that the EPs in hotels contribute to cost savings mainly related to water and energy [5,50,51].

Furthermore, the adoption of EPs can also contribute to improving the competitiveness of the business by improving its image, both from an internal and an external perspective, thereby helping as a factor of differentiation [33,52]. Thus, businesses adopt EPs to attract a new class of consumers with greater environmental awareness to ensure a better position for the business in the market $[38,53]$ and to make employees more motivated and committed to the company $[16,54,55]$. In the hotel sector, the implementation of these practices also allows a differentiation of hotels $[20,28]$. Tourists are increasingly more demanding, forcing hotels to adapt to their new tastes and preferences, including a greater respect for the environment. In this manner, by adopting Eps, hotels improve customer loyalty and the public image of the business $[24,28,33]$.

At the level of small businesses, the adoption of Eps helps create a positive public image of the business and also yields an immediate and visible improvement in the efficiency of the organization $[38,56]$.

Based on the literature provided, the following working hypotheses are presented:

\section{H1: The adoption of environmental practices is positively related to operational improvements in the small hotel industry. \\ H2: The adoption of environmental practices is positively related to competitiveness in the small hotel industry.}

Before concluding the hypotheses, it is important to bear in mind that the main objective and the greatest contribution of this article are to establish whether there are differences in the impact of EPs 
in the hotel sector on operational performance and competitiveness, depending on whether the EPs have been adopted voluntarily or due to external pressure. Considering that, in the hotel sector, the reasons why companies adopt EPs stem from external pressures $[14,33]$ and from the perception that voluntarily adopting these practices is good for business $[19,20,22-24,39,40]$ and also considering that the hotel sector is very proactive in voluntarily adopting EPs $[4,6,13]$, the third and final hypothesis is proposed as follows:

H3: The adoption of environmental practices in the small hotel sector affects improvements in operational performance and competitiveness more when these practices are voluntarily adopted than when they are adopted due to pressure or obligation.

Figure 1 summarizes the model that is used to verify whether there are significant differences in the impact of EPs on operational performance and competitiveness, with a prior segmentation of the sample.

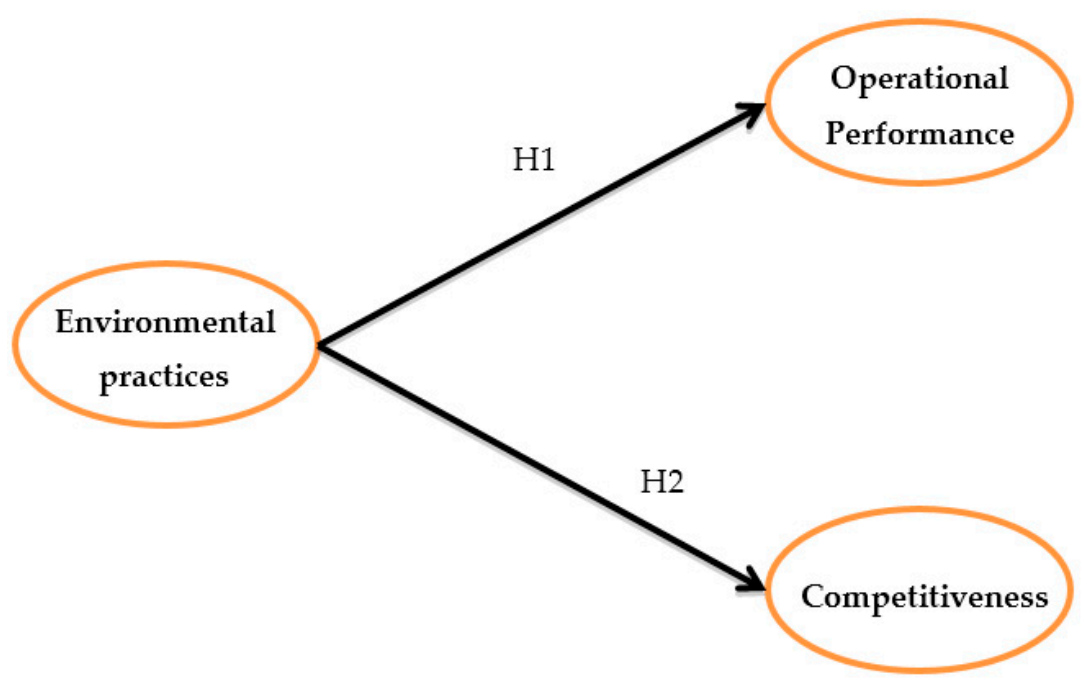

Figure 1. Model to be verified.

\section{Sample and Methodology}

\subsection{Sample and Data Collection}

The data used in this paper were obtained from a survey conducted among 210 managers of small hotels from Catalonia. All data were collected in 2014.

The main reason for focusing our study on hotels is because the tourism sector represents $10.2 \%$ of the Spanish GPD and more than 11\% of total national employment [26]. In addition, the hotel sector is the greatest economic subsector of the tourism industry. These percentages demonstrate the importance of this sector in Spain.

The questionnaire was divided into three main sections: EPs, operational performance due to EPs and competitiveness. In addition, to classify the respondents by type, a section was added at the end of the survey to analyze the specific characteristics of each company. Aspects such as size, the age of the respondent, gender, the type of business, the number of years since inception and the number of employees, were included in this section. Table 1 shows the profile of the companies that responded to the survey.

In addition, we must note that the vast majority of hotels (over $80 \%$ ) were three- or four-star hotels and had a total average of 38 employees.

Finally, it is important for this study that the questionnaire contained a question about whether the hotel had adopted EPs voluntarily or was under pressure from the environment, because the 
main objective of this research is to analyze whether the positive impact of certain environmental actions by hotels on results is greater when these actions are taken voluntarily. Of the total sample, 97 hotels $(46.2 \%)$ replied that they performed some type of practice of environmental protection due to regulations and pressure from the environment, and 113 hotels (53.8\%) answered that they performed environmental prevention actions because they felt committed. Other control questions were included in the questionnaire in order to assure subjective opinions.

Table 1. Profile of companies included in the sample.

\begin{tabular}{ccc}
\hline Typology & \multicolumn{2}{c}{ Hotels } \\
\hline Independent & 121 & $57.62 \%$ \\
National group & 74 & $35.24 \%$ \\
Foreign group & 11 & $5.24 \%$ \\
Franchise & 4 & $1.90 \%$ \\
Total & $\mathbf{2 1 0}$ & $\mathbf{1 0 0 . 0 0 \%}$ \\
\hline
\end{tabular}

\subsection{Measures}

To conduct the statistical analysis, three dimensions were introduced into the model according to the literature review (see Table 2 in the previous studies where the same variables were used to measure EPs, operational performances and competitiveness). Table 2 summarizes all of the constructs and their constituent variables (a seven-point Likert scale was used to operationalize the constructs; all managers were asked for their opinion on the importance of all of the variables, with $1=$ "completely disagree" and 7 = "completely agree"). In addition, as noted by [28], we used a subjective approach as suitable because executives are typically less reluctant to provide subjective information than objective data: the fact of obtaining information on business performance according to subjective methods is consistent with objective measures.

Table 2. Constructs and variables.

\begin{tabular}{|c|c|}
\hline Code & Definition \\
\hline \multicolumn{2}{|r|}{ Environmental Practices (ENV) $[20,23,32,57,58]$} \\
\hline ENV1 & Your organization buys ecological products \\
\hline ENV2 & $\begin{array}{l}\text { Your organization has reduced the use of cleaning products that are harmful to } \\
\text { the environment }\end{array}$ \\
\hline ENV3 & Your organization implements energy-saving practices \\
\hline ENV4 & Your organization implements water-saving practices \\
\hline ENV5 & Your organization implements the selective collection of solid wastes \\
\hline ENV6 & The company trains its employees on environmental matters \\
\hline \multicolumn{2}{|r|}{ Operational performance (OP) $[16,32,47,49,59]$} \\
\hline OP1 & $\begin{array}{l}\text { Environmental protection activities allow your organization to reduce the total } \\
\text { cost of operations }\end{array}$ \\
\hline OP2 & $\begin{array}{l}\text { Environmental protection activities allow your organization to reduce water } \\
\text { and electricity consumption }\end{array}$ \\
\hline OP3 & $\begin{array}{l}\text { Environmental protection activities allow your organization to reduce the risk } \\
\text { of accidents and legal action }\end{array}$ \\
\hline OP4 & $\begin{array}{l}\text { Environmental protection activities allow your organization to enable the } \\
\text { administration to win public support for cleaner production }\end{array}$ \\
\hline \multicolumn{2}{|r|}{ Competitiveness (COMP) [16,20,32,37,54,55] } \\
\hline COMP1 & The company's image has been improved \\
\hline COMP2 & The customer satisfaction level is higher than that of competitors \\
\hline COMP3 & The employee satisfaction level is higher than that of competitors \\
\hline COMP4 & The ability to maintain a market presence in times of crisis is higher \\
\hline COMP5 & Sales have increased more than those of competitors \\
\hline
\end{tabular}




\subsection{Methodology}

To contrast the hypotheses that compose the model, the statistical analysis was divided into two parts. First, a factor analysis was conducted to determine which of the variables compose each construct. For an item to be accepted in this exploratory factor analysis (EFA), it must meet a minimum factor loading of 0.5. For the resulting items, a confirmatory factor analysis (CFA) was conducted. In this case, and with the goal of establishing dimensions with a high degree of consistency, only items with a loading greater than or close to 0.7 are accepted.

Next, the internal consistency and reliability of each of the resulting dimensions were analyzed using Cronbach's alpha coefficient and the average variance extracted (AVE). In all cases, the values are higher than the thresholds defined in the literature, i.e., 0.7 for Cronbach's alpha [60] and 0.5 for AVE [61]. The discriminant validity between constructs was also analyzed, showing that the correlations are lower than the square root of the AVE.

Second, after the dimensions were defined, the relationship between them was analyzed. Using the EQS software and a maximum likelihood model, the main statistics were analyzed to determine the goodness of fit of the model. Finally, to detect possible differences between subsectors and using the same EQS software, a multi-group analysis was conducted to study possible behavioral differences in hotels where managers are committed to the care of the environment and where managers adopt EPs due to pressure from different stakeholders.

\section{Results}

\subsection{Full Sample}

Table 3 shows the results of the factor analyses of the principal components. The main statistics for validating internal consistency and reliability are also included. Some items that meet the requirements of the EFA do not exceed the threshold of 0.7 in the CFA; therefore, they are all excluded from the analysis. Finally, it is noteworthy that the statistical values for internal consistency and reliability exceed the minimum required; this fact demonstrates the high consistency of the dimensions.

Table 3. Factor analyses of the dimensions. AVE, average variance extracted.

\begin{tabular}{|c|c|c|c|c|}
\hline Dimension & Code & $\begin{array}{c}\text { Exploratory } \\
\text { Factor Analysis }\end{array}$ & $\begin{array}{l}\text { Confirmatory } \\
\text { Factor Analysis }\end{array}$ & $\begin{array}{l}\text { Internal Consistency and } \\
\text { Reliability Statistics }\end{array}$ \\
\hline \multirow{6}{*}{$\begin{array}{l}\text { Environmental } \\
\text { Practices }\end{array}$} & ENV1 & 0.808 & 0.701 & \multirow{6}{*}{$\begin{array}{c}\text { Cronbach's alpha: } 0.885 \\
\text { Composite reliability: } 0.889 \\
\text { AVE: } 0.672\end{array}$} \\
\hline & ENV2 & 0.801 & 0.708 & \\
\hline & ENV3 & 0.854 & 0.896 & \\
\hline & ENV4 & 0.897 & 0.944 & \\
\hline & ENV5 & 0.795 & - & \\
\hline & ENV6 & 0.742 & - & \\
\hline \multirow{4}{*}{$\begin{array}{l}\text { Operational } \\
\text { Performance }\end{array}$} & OP1 & 0.888 & 0.888 & \multirow{4}{*}{$\begin{array}{c}\text { Cronbach's alpha: } 0.866 \\
\text { Composite reliability: } 0.872 \\
\text { AVE: } 0.696\end{array}$} \\
\hline & OP2 & 0.861 & 0.859 & \\
\hline & OP3 & 0.857 & 0.749 & \\
\hline & OP4 & 0.761 & - & \\
\hline \multirow{5}{*}{ Competitiveness } & COMP1 & 0.825 & 0.807 & \multirow{5}{*}{$\begin{array}{c}\text { Cronbach's alpha: } 0.872 \\
\text { Composite reliability: } 0.876 \\
\text { AVE: } 0.640\end{array}$} \\
\hline & COMP2 & 0.885 & 0.889 & \\
\hline & COMP3 & 0.823 & 0.734 & \\
\hline & COMP4 & 0.822 & 0.761 & \\
\hline & COMP5 & 0.673 & - & \\
\hline
\end{tabular}

Table 4 confirms the discriminant validity of the constructs. In all cases, it is shown that each construct is more closely related to its own dimensions than to the dimensions of the other constructs. 
Table 4. Discriminant validity.

\begin{tabular}{cccc}
\hline & ENV & OP & COMP \\
\hline ENV & $0.819 *$ & & \\
OP & 0.702 & $0.834 *$ & $0.799 *$ \\
COMP & 0.578 & 0.568 & 0. \\
\hline \multicolumn{4}{c}{ * Square root of the AVE in the diagonal. }
\end{tabular}

Next, the structural equation modelling (SEM) is assessed using the EQS software, according to the maximum likelihood method. The results are shown in Table 5. Considering all of the indices together, we assert the fit of the model because it meets the recommendations made by [62-65] and because at least three fit statistics indicate an acceptable fit [66]. According to [54], the result of dividing the chi-square test by its degrees of freedom must be smaller than three. According to [55] and [56], the goodness of fit index (GFI) must be greater than 0.8; this fact indicates an acceptable model fit. In addition, the standardized root mean square residual (SRMR) value must be smaller than 0.1 to indicate a good model fit. Finally, the comparative fit index (CFI), Bentler-Bonett normed fit index (BBNFI) and Bentler-Bonett non-normed fit index (BBNNFI) values must be higher than 0.9.

Table 5. Goodness of fit of the model.

\begin{tabular}{lcc}
\hline \multicolumn{1}{c}{ Assessment Item } & Values & Ideal Value \\
\hline$X^{2} /$ df (normed chi-squared) & 2.334 & $<3$ \\
GFI (goodness of fit) & 0.915 & $>0.8$ \\
Bentler-Bonett normed fit index (BBNFI) & 0.938 & $>0.9$ \\
Bentler-Bonett non-normed fit index (BBNNFI) & 0.952 & $>0.9$ \\
CFI (comparative fit index) & 0.963 & $>0.9$ \\
SRMR (standardized root mean square residual) & 0.07 & $<0.1$ \\
\hline
\end{tabular}

Finally, the standardized solution of the causal model is presented in Figure 2. All of the hypotheses are supported at the significance level of 0.05 .

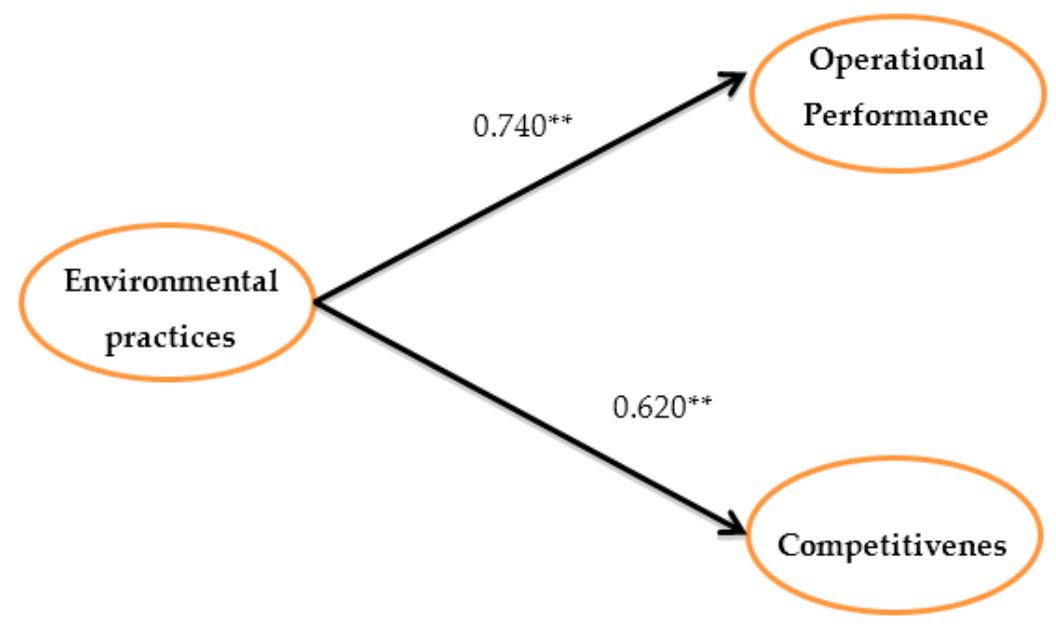

Figure 2. Standardized solution of the causal model. ${ }^{* *} p$-value significant at the 0.05 level.

In summary, the results indicate that, when we group all hotels in one unique sample and analyze the sample as a whole, EPs have a positive impact on the companies' operational performance and their competitiveness.

Thus, the adoption of EPs in the small hotel industry is positively related to operational improvements, reducing the total cost of operations, water and electricity consumption and the 
risk of accidents and legal action; furthermore, EPs enable the administration to win public support for cleaner production. This conclusion is in line with the results obtained in previous studies on hotels [5,20,50,51], and therefore, H1 is accepted.

In regard to the external effect of the implementation of EPs in the small hotel industry, the adoption of EPs is also positively related to competitiveness, improving the company's image, leading to higher customer and employee satisfaction, creating a better market presence and increasing sales. Therefore, in line with the results obtained in previous works on hotels [20,28,33], H2 is accepted.

\subsection{Differences between Sub-Samples}

As noted above at the beginning of this section, a multi-group analysis is conducted to study possible behavioral differences in hotels where managers are committed to the care of the environment and where managers adopt EPs due to pressure from different stakeholders. Next, the same multi-group study is conducted to determine in detail where the differences are most pronounced by analyzing each relationship across dimensions.

Tables 6 and 7 show that hotels that have adopted EPs due to the convictions of their top managers obtain better results from the implementation of EPs in the operational performance and competitiveness of their companies.

Table 6. Invariance test for all relationships.

\begin{tabular}{ccc}
\hline & ENV $\rightarrow$ OP & ENV $\rightarrow$ COMP \\
\hline$\Delta X^{2}$ & 4.167 & 3.815 \\
$\Delta$ df & 1 & 1 \\
$p$-value & $0.023^{* *}$ & $0.041^{* *}$ \\
\hline
\end{tabular}

** Statistically significant at the 0.05 level.

Table 7. Standardized values and statistics by sub-sample.

\begin{tabular}{|c|c|c|c|c|}
\hline & & $\mathrm{ENV} \rightarrow \mathrm{OP}$ & $\mathrm{ENV} \rightarrow \mathrm{COMP}$ & Fit Indices ${ }^{1}$ \\
\hline $\begin{array}{c}\text { PRESSURED } \\
n=97\end{array}$ & $\beta$ & $0.673^{* *}$ & $0.567 * *$ & $\begin{array}{c}X^{2} / \mathrm{df}=1.778 \\
\mathrm{GFI}=0.874 \\
\text { BBNFI }=0.879 \\
\text { BBNNFI }=0.924 \\
\text { CFI }=0.942 \\
\text { SRMR }=0.090\end{array}$ \\
\hline $\begin{array}{l}\text { COMMITTED } \\
n=113\end{array}$ & $\beta$ & $0.799^{* *}$ & $0.644^{* *}$ & $\begin{array}{c}X^{2} / \mathrm{df}=2.136 \\
\mathrm{GFI}=0.871 \\
\text { BBNFI }=0.913 \\
\text { BBNNFI }=0.936 \\
\text { CFI }=0.951 \\
\text { SRMR }=0.067\end{array}$ \\
\hline
\end{tabular}

${ }^{1}$ Maximum likelihood; ${ }^{* *}$ significant at the 0.05 level.

The results show that, examining the segmented analysis of the sample, the adoption of EPs in small hotels has a greater effect on the improvements in operational performance and competitiveness as a whole when these practices are voluntarily adopted than when they are adopted due to pressure or legislative obligations. Thus, $\mathrm{H} 3$ is accepted. This study strengthens the results of previous studies that claim that hotel managers tend to apply EPs when they perceive that these practices are strategic for the business and help them in seeking some type of market differentiation $[19,20,22-24,39,40]$. 


\section{Discussion and Conclusions}

This paper examines the links between the application of environmental practices and operational performance and competitiveness to study possible behavioral differences in hotels where managers are committed to the care of the environment and where managers adopt EPs due to the pressure of different stakeholders. A model is proposed and was tested on a sample of 210 managers of small hotels from Catalonia, a regional community in Spain, in 2014. The findings provide relevant implications to practitioners related to the hospitality industry for the development of successful hotel operations and management.

This study confirms that, in small hotels, the implementation of EPs yields internal improvements that enhance efficiency and that result in a better utilization of resources with consequent cost savings. It cannot be overlooked that there is a positive effect on workers and their performance, efficiency and the ability to meet the expectations of the increasingly demanding consumer. In regard to the external effect of the implementation of EP, the results suggest that the potential ability to attract customers who are sensitive to environmental issues and the improvement in image make the implementation of EPs profitable, thus contradicting many researchers who argue that, for small businesses, the investment is greater than the benefit from implementing these practices.

As a major contribution by this study to the literature, we can observe that the adoption of EPs in a small hotel has a greater effect on improvements in operational performance and competitiveness when these practices are voluntarily adopted than when they are adopted due to pressure or legislative obligations. This finding highlights the need to redouble the efforts of the tourism sector, and particularly of the hotel industry, to voluntarily implement EPs [4,13]. As noted by [28], to be proactive in the hospitality sector, complex changes in several areas must be implemented with regard to business practices, design or the employees of the organization, for example [67]. In addition, it will be necessary for hotels to reach an advanced understanding of environmental changes related to customer needs, the movements of competitors and the development of new technologies.

Another important result of this study is that, in all cases, for both the total and the segmented samples, the results show that the application of EPs has a greater effect on operational performance than on the competitiveness of small hotels. Thus, this finding suggests that the implementation of EPs allows small hotels to be more efficient in terms of costs, beyond the results obtained in terms of the image directed towards their stakeholders. This result is relevant for the hotel sector and specifically for encouraging small hotel managers to implement EPs because, unlike in the industrial sector, service sector businesses are generally not aware of the benefits generated by implementing these types of practices, and this lack of awareness is even more pronounced in the case of small businesses [32].

In summary, the implications for managers of small hotels to be proactive in implementing EPs in their businesses undertake two distinct pathways; on the one hand, there is an opportunity to improve business and achieve long-term economic savings in terms of reduced energy costs, reduced costs of eliminating waste, reduced costs control, increased sales to a public that is increasingly sensitized to environmental issues and easier access to credit lines, as well as advantages in obtaining grants, subsidies and tax advantages for companies located in countries where their governments are sensitive and tend to favor the implementation of measures of environmental enterprises. On the other hand, it is undoubtedly important to note that increased environmental awareness on the part of society makes any project that is respectful of the environment well regarded by external stakeholders, which would directly impact the image and reputation of the business in terms of improved relations with the local community, major national and international competitiveness over competitors, a decreased risk of incidents and, in turn, a lower risk of legal claims and penalties due to better adaptation to the legislation, ultimately improving the economic performance of the company and its image.

The final conclusion is that governments must not only regulate, but also promote awareness actions in small and medium-sized (SME) tourism companies to improve the environment. This argument is in line with the statement by the United Nations World Tourism Organization [68], which concluded that raising awareness among tourism planners and entrepreneurs about the design 
and implementation of sustainable tourism strategies is important because doing so allows the proper conservation of the touristic resources that attract visitors and that are a source of wealth for the inhabitants of the destination. In addition to improving the economic and financial results of the business and its image, both internally and externally, this awareness improves the environment as a whole. Therefore, SME tourism companies must understand that not only the environment, but also they themselves will benefit.

This study has limitations derived from the geographic area where the sample was obtained, which may make generalizations to other countries/regions difficult, although this sample can be an indicator that explains the overall behavior of small hotels in Spain. However, performing new empirical research that makes it possible to reaffirm the conclusions is recommended.

Ultimately, this study raises other questions that can be the subject of future research, especially for small hotels that adopt EPs and consider how much the fact of having some environmental certification can be a distinguishing factor in achieving better results. For this reason, an analysis of small hotels that adopt EPs to examine whether there are significant differences due to being certified is proposed. Similarly, performing a comparative analysis between large and small hotels that have environmental certifications to assess whether there are significant differences in the impact of EPs depending on hotel size could also be of interest.

Acknowledgments: The authors would like to thank the anonymous reviewers for their contributions.

Author Contributions: Llorenç Bagur conceived of, designed and performed the experiments based on the literature review conducted. Dolors Celma and Josep Patau analyzed the data and contributed reagents/materials/analysis tools. All authors wrote the conclusions and recommendations of the paper. All authors agree on the final version.

Conflicts of Interest: The authors declare no conflicts of interest.

\section{References}

1. Frontur. Movimientos Turísticos en Frontera, 2014. Ministerio de Industria, Energía y Turismo, Turespaña. Available online: http:/ / www.iet.tourspain.es (accessed on 3 May 2016). (In Spanish)

2. Observatori d'Empresa i Ocupació-GENCAT. Resum de Resultats Anuals 2014. Dipòsit Legal B-4142-2015, 2016. Available online: http://observatoriempresaiocupacio.gencat.cat/web/.content/02_-_ambits_tematics/ turisme/09_-_resultats_anuals/2014/arxius/Resum_resultats_anuals_2014.pdf (accessed on 19 July 2016).

3. Wu, K.J.; Liao, C.J.; Tseng, M.L.; Chou, P.J. Understanding Innovation for Sustainable Business Management Capabilities and Competencies under Uncertainty. Sustainability 2015, 7, 13726-13760. [CrossRef]

4. Rodríguez-Antón, J.M.; Alonso-Almeida, M.M.; Celemín, M.; Rubio, L. Use of different sustainability management systems in the hospitality industry. The case of Spanish hotels. J. Clean Prod. 2012, 22, 76-84. [CrossRef]

5. Claver, E.; Pereira, J.; Molina, J.F.; Tarí, J.J. Certificación en Calidad y Medio Ambiente y su Relación con el Rendimiento Empresarial: Evidencia en el Sector Hotelero Español; Departamento de Organización de Empresas, Universidad de Alicante: Alicante, Spain, 2010; Volume 47-48, pp. 25-37.

6. Bonilla, M.; Avilés, C. Analysis of environmental statements issued by EMAS certified Spanish hotels. Cornell Hosp. Q. 2008, 49, 381-394. [CrossRef]

7. Khanna, M.; Speir, C. Motivations for Proactive Environmental Management. Sustainability 2013, 5, 2664-2692. [CrossRef]

8. Schmidheiny, S. Changing Course: A Global Business Perspective on Development and the Environment; MIT Press: Cambridge, UK, 1992.

9. Starik, M.; Marcus, A. Introduction to the special research forum on the management of organizations in the natural environment: A field emerging from multiple paths, with many challenges ahead. Acad. Manag. J. 2000, 43, 539-547. [CrossRef]

10. Miles, M.; Covin, J. Environmental marketing: A source of reputational, competitive and financial advantage. J. Bus. Ethics 2000, 23, 299-311. [CrossRef]

11. Poksinska, B.; Jörn Dahlgaard, J.; Eklund, J.A. Implementing ISO 14000 in Sweden: Motives, benefits and comparison with ISO 9000. Int. J. Qual. Reliab. Manag. 2003, 20, 585-606. [CrossRef] 
12. Zutshi, A.; Sohal, A. Environmental management system adoption by Australasian organisations: Part 1: Reasons, benefits and impediments. Technovation 2004, 24, 335-357. [CrossRef]

13. Bonilla-Priego, M.J.; Nájera, J.J.; Font, X. Environmental management decision-making in certified hotels. J. Sustain. Tour. 2011, 19, 361-381. [CrossRef]

14. Alonso-Almeida, M.M.; Rodríguez-Antón, J.M. Organisational behaviour and strategies in adoption of certified management systems. An analysis of the Spanish hotel industry. J. Clean Prod. 2011, 19, 1455-1463. [CrossRef]

15. Ayuso, S. Comparing voluntary policy instruments for sustainable tourism: The experience of the Spanish hotel sector. J. Sustain. Tour. 2007, 15, 144-159. [CrossRef]

16. Enz, C.A.; Siguaw, J.A. Best hotel environmental practices. Cornell Hotel Restaur. Adm. Q. 1999, 40, 72-77. [CrossRef]

17. Goodman, A. Implementing sustainability in service operations in Scandic Hotels. Interfaces 2000, 30, $202-214$. [CrossRef]

18. Tarí, J.J.; Claver-Cortés, E.; Pereira-Moliner, J.; Molina-Azorín, J.F. Levels of quality and environmental management in the hotel industry: Their joint influence on firm performance. Int. J. Environ. Manag. 2010, 29, 500-510.

19. Carmona-Moreno, E.; Cespedes-Lorente, J.; De Burgos-Jimenez, J. Environmental strategies in Spanish hotels: Contextual factors and performance. Serv. Ind. J. 2004, 24, 101-130. [CrossRef]

20. Molina-Azorín, J.F.; Claver-Cortes, E.; Pereira-Moliner, J.; Tarí, J.J. Environmental practices and firm performance: An empirical analysis in the Spanish hotel industry. J. Clean Prod. 2009, 17, 516-524. [CrossRef]

21. Singal, M. The link between firm financial performance and investment in sustainability initiatives. Cornell Hosp. Q. 2013, 55, 19-30. [CrossRef]

22. Claver, E.; López, M.D.; Molina, J.F.; Tarí, J. Environmental management and firm performance: A case study. J. Environ. Manag. 2007, 84, 606-619. [CrossRef] [PubMed]

23. Alvarez-Gil, M.J.; Burgos-Jiménez, J.; Cespedes-Lorente, J.J. An analysis of environmental management, organizational context and performance of Spanish hotels. Omega 2001, 29, 457-471. [CrossRef]

24. Lee, J.; Hsu, L.; Han, H.; Kim, Y. Understanding how consumers view green hotels: How a hotel's green image can influence behavioural intentions. J. Sustain. Tour. 2010, 18, 901-914. [CrossRef]

25. Cormier, D.; Ledoux, M.J.; Magnan, M. The informational contribution of social and environmental disclosures for investors. Manag. Decis. 2011, 49, 1276-1304. [CrossRef]

26. Lopez, M.; Molina, J.; Claver, E. The whole relationship between environmental variables and firm performance: Competitive advantage and firm resources as mediator variables. J. Environ. Manag. 2009, 90, 3110-3121. [CrossRef] [PubMed]

27. Delmas, M.; Hoffman, V.; Kuss, M. Under the tip of the iceberg: Absorptive capacity, environmental strategy and competitive advantage. Bus. Soc. 2011, 50, 116-154. [CrossRef]

28. Fraj, E; Matute, J; Melero, I. Environmental strategies and organizational competitiveness in the hotel industry: The role of learning and innovation as determinants of environmental success. Tour. Manag. 2015, 46, 30-42. [CrossRef]

29. Diario Oficial de la Unión Europea. Directiva 2014/52/UE del Parlamento Europeo y del Consejo de 16 de Abril de 2014. Available online: https://www.boe.es/doue/2014/124/L00001-00018.pdf (accessed on 6 April 2016).

30. Boletín Oficial del Estado. Ley 20/2009, de 4 de diciembre, de prevención y control ambiental de las actividades. BOE 2010, 12, 3062-3123. (In Spanish)

31. Casadesús, M.; Marimon, F.; Alonso-Ameida, M. The future of standardised quality management in tourism: Evidence from the Spanish tourist sector. Serv. Ind. J. 2010, 30, 2457-2474. [CrossRef]

32. Bagur-Femenias, L.; Llach, J.; Alonso-Almeida, M. Is the adoption of environmental practices a strategical decision for small service companies? An empirical approach. Manag. Decis. 2013, 51, 41-62. [CrossRef]

33. Chan, E.; Wong, S. Motivations for ISO 14001 in the hotel industry. Tour. Manag. 2006, 27, 481-492. [CrossRef]

34. INE. Notas de Prensa, 2014. Available online: http://www.ine.es/notasdeprensa (accessed on 3 May 2016).

35. Weng, H.H.; Chen, J.S.; Chen, P.C. Effects of Green Innovation on Environmental and Corporate Performance: A Stakeholder Perspective. Sustainability 2015, 7, 4997-5026. [CrossRef] 
36. Gombault, M.; Versteege, S. Cleaner production in SMEs through a partnership with (local) authorities: Successes from The Netherlands. J. Clean Prod. 1999, 7, 249-261. [CrossRef]

37. Hillary, R. Environmental management systems and the smaller enterprise. J. Clean Prod. 2004, 12, 561-569. [CrossRef]

38. Fernández-Viñé, M.B.; Gómez-Navarro, T.; Capuz-Rizo, S.F. Eco-efficiency in the SMEs of Venezuela. Current status and future perspectives. J. Clean Prod. 2010, 18, 736-746. [CrossRef]

39. Singels, J.; Ruel, G.; Van de Water, H. ISO 9000 series: Certification and performance. Int. J. Qual. Reliab. Manag. 2001, 18, 62-75. [CrossRef]

40. Pan, J. A comparative study on motivation for and experience with ISO 900 and ISO 14000 certification among far eastern countries. Ind. Manag. Data Syst. 2003, 103, 564-578. [CrossRef]

41. Duran, I.; Bikfalvi, A.; Llach, J. New facets of quality. A multiple case study of green cosmetic manufacturers. Eur. Acc. Manag. Rev, 2014, 1, 43-61.

42. Del Brío, J.; Junquera, B. Competitividad y situación medioambiental de los centros productivos certificados en España. Universia Bus. Rev. 2004, 4, 64-77.

43. Wilkins, H.; Merrilees, B.; Herington, C. Towards an understanding of total service quality hotels. Int. J. Hosp. Manag. 2007, 26, 840-853. [CrossRef]

44. Bravo, R.; Fraj, E.; Matute, J. La estrategia de "ecologismo de empresas" en el sector de bienes de consumo final. Universia Bus. Rev. 2006, 1, 58-73.

45. Murillo, J.; Garcés, C.; Rivera, P. Estrategia empresarial y medio ambiente: Opinión de un grupo de expertos. Universia Bus. Rev. 2004, 4, 52-63.

46. Aragón-Correa, J.A.; Hurtado-Torres, N.; Sharma, S.; García-Morales, V.J. Environmental strategy and performance in small firms: A resource-based perspective. J. Environ. Manag. 2008, 86, 88-103. [CrossRef] [PubMed]

47. Chan, E.S.W.; Hawkins, R. Attitude towards EMSs in an international hotel: An exploratory case study. Int. J. Hosp. Manag. 2010, 29, 641-651. [CrossRef]

48. Boyle, C. Cleaner production in New Zealand. J. Clean. Prod. 1999, 7, 59-67. [CrossRef]

49. Mohamed, S.T. The impact of ISO 14000 on developing world businesses. Renew. Energy 2001, 23, 579-584. [CrossRef]

50. Chan, W.W. Partial analysis of the environmental costs generated by hotels in Hong Kong. Tour. Manag. 2005, 24, 517-531. [CrossRef]

51. Chan, W.W.; Lam, J.C. Energy-saving supporting tourism sustainability: A case of study of hotel swimming pool heat pumps. J. Sustain. Tour. 2003, 11, 74-83. [CrossRef]

52. Kirk, D. Attitudes to environmental management held by a group of hotel managers in Edinburgh. Int. J. Hosp. Manag. 1998, 17, 33-47. [CrossRef]

53. United Nations Environment Programme. Greening Shops and Saving Costs; UNEP DTIE: Paris, France, 2006.

54. Lee, K. Why and how to adopt green management into business organizations? The case study of Korean SMEs in manufacturing industry. Manag. Decis. 2009, 47, 1101-1121.

55. Kassinis, G.I.; Soteriou, A.C. Greening the service profit chain: The impact of environmental management practices. Prod. Oper. Manag. 2003, 12, 386-403. [CrossRef]

56. Fresner, J.; Engelhardt, G. Experiences with integrated management systems for two small companies in Austria. J. Clean Prod. 2004, 12, 623-631. [CrossRef]

57. Coté, R.; Booth, A.; Louis, B. Eco-efficiency and SMEs in Nova Scotia, Canada. J. Clean Prod. 2006, 14, 542-550. [CrossRef]

58. Gavronski, I.; Ferrer, G.; Paiva, E.L. ISO 14001 certification in Brazil: Motivations and benefits. J. Clean Prod. 2008, 16, 87-94. [CrossRef]

59. Blanco, E.; Rey-Maquieira, J.; Lozano, J. Economic incentives for tourism firms to undertake voluntary environmental management. Tour. Manag. 2009, 30, 112-122. [CrossRef]

60. Malhotra, N.K. Marketing Research: An Applied Orientation, 4th ed.; Prentice Hall: Upper Saddle River, NJ, USA, 2004.

61. Barclay, D.; Higgins, C.; Thompson, R. The partial least squares (PLS) approach to causal modeling: Personal computer adoption and use as an illustration. Tech. Stud. 1995, 2, 285-309.

62. Carmines, E.G.; McIver, J.P. Analyzing models with unobserved variables. In Social Measurement: Current Issues; Bohrnstedt, G.W., Borgatta, E.F., Eds.; Sage: Beverly Hills, CA, USA, 1981; pp. 53-86. 
63. Byrne, B.M. Structural Equation Modeling with EQS and EQS/Windows; Sage: Thousand Oaks, CA, USA, 1994.

64. Hu, L.; Bentler, P. Cutoff criteria for fit indexes in covariance structure analysis: Conventional criteria versus new alternatives. Struct. Equ. Model. Multidiscip. J. 1999, 6, 1-55. [CrossRef]

65. Kline, R.B. Principles and Practice of Structural Equation Modeling, 2nd ed.; The Guilford Press: New York, NY, USA, 2005.

66. Schermelleh-Enge, K.; Moosbrugger, H.; Müller, H. Evaluating the fit of structural equation models: Tests of significance and descriptive Goodness-of-Fit measures. Methods Psychol. Res. Online 2003, 8, 23-74.

67. Sharma, S. The mediating effect of information availability between organization design variables and environmental practices in the Canadian hotel industry. Bus. Strategy Environ. 2009, 18, 266-276. [CrossRef]

68. UNWTO (United Nations-World Tourism Organization). World Tourism Day 2010 to Cerebrate Tourism and Biodiversity, 27 September 2010. China. Available online: http://www2.unwto.org/content/whytourism (accessed on 18 July 2016).

(C) 2016 by the authors; licensee MDPI, Basel, Switzerland. This article is an open access article distributed under the terms and conditions of the Creative Commons Attribution (CC-BY) license (http://creativecommons.org/licenses/by/4.0/). 